\title{
- \\ Use of photodynamic inactivation for in vitro reduction of prevalent bacteria in Fournier's Gangrene
}

Nalisson Marques Pereira ${ }^{1}$, Luciano Santos Feitosa ${ }^{1}$, Ricardo Scarparo Navarro ${ }^{1}$, Dora Inés KozusnyAndreani ${ }^{1}$, Naacia Marques Pereira Carvalho ${ }^{1}$

${ }^{1}$ Departamento de Engenharia Biomédica, Universidade Brasil, São Paulo, SP, Brasil

\section{ABSTRACT}

Fournier's Gangrene (FG) is an infectious disease caused by several synergic microbes, with high morbidity and mortality rates; therefore, the search for new less invasive and mutilating treatments, with faster recovery, has been proposed. Surgical intervention, the use of several systemic and topic antibiotics, and hyperbaric oxygen therapy are currently the best approach for the treatment of these patients. The use of Photodynamic Inactivation (PDI) aims to lower morbidity and mortality, by reducing bacterial microbiota and speeding wound healing. In the present study, viable bacteria were separated in four groups: Group L-/F- (no irradiation with red laser and absence of methylene blue photosensitizer), Group L-/F+ (no irradiation with red laser and presence of methylene blue), Group L+/F- (irradiation with red laser and absence of methylene blue) and $\mathrm{L}+/ \mathrm{F}+$ (irradiation with red laser associated to methylene blue). In all groups, exposure time to treatment was 5, 10 and 15 minutes. The concentration of methylene blue photosensitizer was $0.1 \mathrm{mg} / \mathrm{L}$, and the dose of red laser (660nm wave length) was $176.9 \mathrm{~mW} / \mathrm{cm}^{2}$. Following irradiation, the reduction of number of bacteria was evaluated, and the results were expressed in colony forming units (CFU) and as exponential reduction. As the main results, in the $\mathrm{L}+\mathrm{F}+$ group, there were no Clostridium perfringens and Staphylococcus aureus CFUs and there was a reduction of Escherichia coli that was not observed in the other groups.

\section{ARTICLE INFO}

\section{Keywords:}

Fournier Gangrene; Methylene

Blue; Clostridium perfringens

Int Braz J Urol. 2018; 44: 150-5

Submitted for publication:

May 18, 2017

Accepted after revision:

October 30, 2017

Published as Ahead of Print:

November 22, 2017

\section{INTRODUCTION}

Fournier's Gangrene (FG) is a polymicrobial infection caused by several aerobic and anaerobic microorganisms, that, synergistically, causes a necrotizing fasciitis, involving genitals, perineum and perianal region $(1,2)$. The most common microorganisms of FG are: gram positive aerobes, in special Staphylococcus aureus, Staphylococcus epidermidis, Streptococcus viridans and Streptococcus faecalis. Among anaerobes, the most common are Bacteroides fragilis, Bacteroides melaninogenicus, Gram po- sitive coccus and Clostridium sp. Among Gram negative aerobes, it is observed the presence of Escherichia coli, Klebsiella pneumoniae, Pseudomonas aeruginosa and Proteus mirabilis. Synergistically, these bacteria act by different mechanisms and rapidly disseminates the infectious process (3).

Among microorganisms that cause FG, the most frequent isolated aerobes are: Escherichia coli, Klebsiella pneumonie and Staphylococcus aureus, and the most frequent anaerobes are Bacteroides fragilis and Clostridium species (4). Aside from bacteria, other microorganisms 
such as fungus, yeasts and virus may be present in FG and this fact is leading many researchers to search for alternative therapies to efficiently eliminate these pathogens. Photodynamic treatment (PDT) may represent an efficient treatment to eliminate these germs (5). Recent studies show that Photodynamic Inactivation (PDI) may be a viable alternative, since the action mode of photosensitizer (PS) over microbial cells is markedly different from the typical action of most antibiotic drugs (6).

PDI is based on topic or systemic administration of a non-toxic PS, followed by low dose irradiation of visible light with adequate wave length (7). This technique destroys target cells by means of oxidation that cause cellular lysis and inactivation of membrane proteins (8). In the presence of oxygen present in the cells, activated PS may react with neighbor molecules by means of transfer of electrons or hydrogen, producing free radicals (reaction type I) or transfer of energy to oxygen (reaction type II), producing oxygen singlet. Both ways cause cellular death $(9,10)$. Therefore, in view of the potential of this technique to treat bacterial infections, among other microorganisms, the objective of this work was to inactivate prevalent bacteria in FG, using PDI.

Among the most used photosensitizers (PS) in PDI, some stand out: natural occurring porphyrins, particular Protoporphyrin IX, chlorophylls and biocompatible PS that don't generate toxicity at dark (9). The most promising for human use for PDI are chlorines and phenothiazines: they absorb light with high wave length with adequate penetration in live tissues with low toxicity.

The use of PDI in medicine is becoming more relevant, since it is a reality in the treatment of diseases such as cancer, periodontitis, dermatologic diseases such as actinic keratosis and common acne, venereal diseases such as acuminate condyloma, among others (11-13).

Most studies in Urology using Photodynamic Therapy (PDT) are related to malign tumors such as bladder and prostate cancer $(14,15)$; our study aims to investigate the role of PDT in treating infectious diseases such as Fournier's Gangrene, one of the most morbid diseases in Urology.

\section{MATERIAL AND METHODS}

\section{Bacterial Lines}

It was used lines of Escherichia coli CCCD (Coleção de Culturas Cefar Diagnóstica) Staphylococcus aureus CCCD S003, (CEFAR Diagnóstica, Brasil), and Clostridium perfringens ATCC13124 (American Type Culture Collection). Culture media used included Tryptic Soy Agar (TSA, Oxoid ${ }^{\circledR}$ ) supplemented with defibrinated goat blood (5\%) for culture of S. aureus and C. perfringens, and for $E$. coli it was used agar eosin methylene blue (EMB, Oxoid $\left.^{\circledR}\right)$. Inoculums were prepared in Tryptic Soy Broth culture media (TSB, Oxoid ${ }^{\circledR}$ ).

Preparation of methylene blue and red laser PS methylene blue (Fórmula e Ação, São Paulo, SP, Brazil) was used at the concentration of $0.1 \mathrm{mg} / \mathrm{mL}$ for each sample. PS was dissolved in sterile double distilled water and filtered in a sterile membrane (Millipore, São Paulo, Brazil). Source of light used was red laser (Recover, MMOptics ${ }^{\circledR}$, São Carlos, Brazil), with wavelength of $660 \mathrm{~nm}$, energy density of $26.3 \mathrm{~J} / \mathrm{cm}^{2}$, energy of $10 \mathrm{~J}$, potency $100 \mathrm{~mW}$. Periods of 5, 10 and 15 minutes of irradiation were used in an area of $0.56 \mathrm{~cm}^{2}$, that generated an irradiation of $176.9 \mathrm{~mW} / \mathrm{cm}^{2}$, according to Junqueira et al. protocol (16).

\section{Preparation of bacterial samples and photosen-} sitization

Bacterial lines were incubated in Tryptic Soy Broth culture media (TSB Oxoid ${ }^{\circledR}$ ), for 24 hours at $37^{\circ} \mathrm{C}$, Escherichia coli and Staphylococcus aureus in aerobic conditions and Clostridium perfringens in anaerobic environment. After that period, they were centrifuged at 4,000 rpm for 10 minutes; the supernatant was discharged and the pellet was resuspended in sterile solution of $\mathrm{NaCl}$ $0.5 \%$ and again centrifuged. This procedure was repeated five times. The obtained pellet was resuspended in $1 \mathrm{~mL}$ of sterile $\mathrm{NaCl} 0.5 \%$ solution. Next, from a suspension of $10^{6}$ viable cells/mL of Escherichia coli, Staphylococcus aureus and Clostridium perfringens, 24 essays were performed, six for each experimental group. These essays were divided in 4 experimental groups: Group L-/F- (no irradiation with red laser and absence of methylene blue 
photosensitizer), Group L-/F+ (no irradiation with red laser and presence of methylene blue), Group $\mathrm{L}+/ \mathrm{F}$ - (irradiation with red laser and absence of methylene blue) and $\mathrm{L}+\mathrm{F}+$ (irradiation with red laser associated to methylene blue). Microbial sample of group L-/F- included 1.0mL of bacterial suspension and $0.05 \mathrm{~mL}$ of saline; microbial samples of groups $\mathrm{L}-/ \mathrm{F}+$ and $\mathrm{L}+/ \mathrm{F}+$ included $1.0 \mathrm{~mL}$ of bacterial suspension and $0.05 \mathrm{~mL}$ of methylene blue solution. After preparation, microorganisms remained for 15 minutes at $36^{\circ} \mathrm{C}$ incubated in methylene blue $(0.1 \mathrm{mg} / \mathrm{mL})$ in dark environment and, next, they were irradiated with red laser. In every cycle of 5 minutes (in a total of 15 minutes), a sample of $0.1 \mathrm{~mL}$ was removed and cultured in blood agar media for S. aureus and C. perfringens and EMB agar for E. coli. Bacterial suspension was evenly distributed with the aid of Drigalski sterile loops and the plates were incubated at $37^{\circ} \mathrm{C}$ for 24 hours. After that period, it was performed the counting of colonies to evaluate the photodynamic activity over bacterial lines. All procedures were performed in triplicates. Results were expressed in colony forming units (CFU). After final count of bacterial CFUs, final results were expressed in log and exponential regression.

\section{Statistical analysis}

Data were statistically analyzed by analysis of variance (ANOVA) for totally randomized experiments, with statistical $\mathrm{F}$ calculus and their respective $p$-values. When $p<0.05$, media of treatments were compared using Tukey method, calculating the minimal significant difference for alpha $(\alpha)=0.05$, using the software Graph Pad Prism 6.

\section{RESULTS}

Results obtained by statistical analysis of variance and Tukey test showed significant reduction of Staphylococcus aureus, Clostridium perfringens and E. coli. Figure-1 and Figure-2 show that, in the presence of laser and absence of PS, bacteria were not sensitive to phototherapy after 5, 10 and 15 minutes of exposure. As observed in the group treated only with me-
Figure 1 - Mean $\mathrm{CFU} / \mathrm{mL}$ of $S$. aureus submitted to the following treatments: saline as control (L-/P-), laser and saline $(\mathrm{L}+/ \mathrm{P}-)$, photosensitizer $(\mathrm{L}-/ \mathrm{P}+)$, and laser and photosensitizer $(\mathbf{L}+\mathbf{P +})$ (Tukey test, $p<0.05)$.

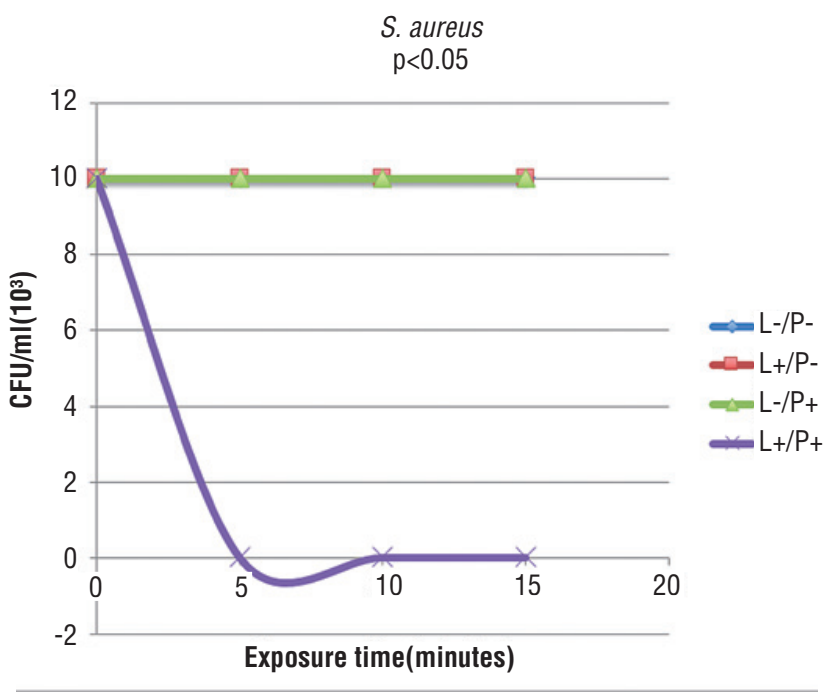

Figure 2 - Mean $\mathrm{CFU} / \mathrm{mL}$ of $C$. perfrigens submitted to the following treatments: saline as control (L-/P-), laser and saline $(\mathrm{L}+/ \mathrm{P}-)$, photosensitizer $\left(\mathrm{L}-/ \mathrm{P}_{+}\right)$, and laser and photosensitizer $\left(L_{+} / P_{+}\right)$(Tukey test, $\left.p<0.05\right)$.

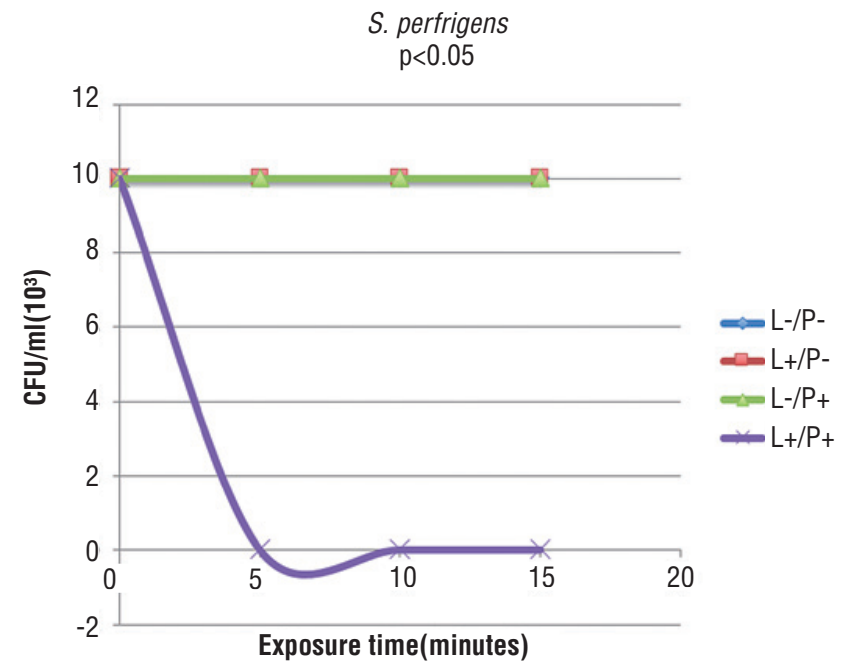

thylene blue, there was no bacterial inactivation in all studied times, demonstrating that microorganisms were not also sensitive to PS alone. In Figures 1-3, graphic lines of control groups overlapped, since results were similar. In the 
Figure 3 - Mean $\mathrm{CFU} / \mathrm{mL}$ of $E$. coli submitted to the following treatments: saline as control (L-/P-), laser and saline $(\mathrm{L}+/ \mathrm{P}-)$, photosensitizer $(\mathrm{L}-/ \mathrm{P}+)$, and laser and photosensitizer $(\mathrm{L}+/$ $\mathrm{P}+$ ). (Tukey test, $\mathrm{p}<0.05$ ).

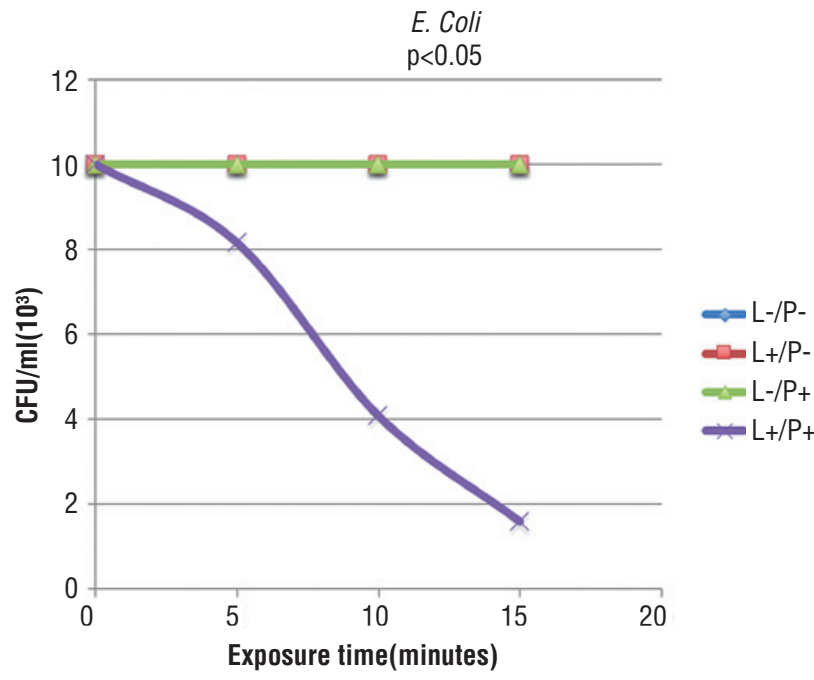

group irradiated and with associated methylene blue, it was observed complete bacterial reduction regardless the increase of treatment time; after 5 minutes, all bacteria were inactivated.

In relation to E. Coli, Figure-3 shows exponential regression of the group treated with laser and methylene blue. This reduction was not time-dependent, since the increase of time to 10 or 15 minutes, lead to a reduction of $03 \log 10$. In the groups treated only with PS (L-F+) and in the groups treated only with laser, it was not observed exponential regression of microorganisms. As shown in Table-1, CFU media (log) of $S$. aureus and $C$. perfrigens bacteria were sensitive to PDI. E. coli species also showed sensitivity to treatment, however with exponential reduction.

\section{DISCUSSION}

This study showed that photodynamic inactivation associated to PS methylene blue was efficient to inactivate Staphylococcus aureus, Clostridium perfringens and E. coli, observed in FG (severe necrotizing fasciitis involving several bacterial species that need new treatments to lower the high rates of morbidity and mortality (1-3)).

The use of these bacteria is in accordance of the fact that in FG, there is multiple simultaneous presence of aerobic and anaerobic microorganisms; we used a sample of each category: a Gram positive aerobic, a Gram negative aerobic and an anaerobic bacteria. The choice of Staphylococcus aureus, Clostridium perfringens and $E$. Coli was based in the fact that in literature, they are referred as the most frequent in their category (4). It was not possible to perform a study with the three bacteria in the same culture conditions, since they are aerobic and anaerobic.

Although methylene blue is used widely due to its cytotoxicity against several microorganisms, such as bacteria and fungus $(8,17)$ this study is the first to show elimination of prevalent bacteria in FG. However, according to Kharkwal et al. (18) and Fuchs et al. (19), correct dose of PS and action of light source are very important in the elimination of microorganisms in PDI. Therefore, the concentration of PS was adjusted to $0.1 \mathrm{mg} / \mathrm{mL}$ in all studied groups: $S$. aureus, C. perfringens and E. coli, at this concentration, methylene blue is not cytotoxic when singly administrated. Our results show that the group treated with only methylene blue (L-/P+) showed microbial growth similar to that observed in the

Table 1 - CFU log reduction of $S$. aureus and C. perfrigens and exponential reduction of $E$. coli.

\begin{tabular}{lcccccc}
\hline Experimental groups & $\mathrm{L}-/ \mathrm{F}-$ & $\mathrm{L}+/ \mathrm{F}-$ & $\mathrm{L}-/ \mathrm{F}+$ & $\mathrm{L}+/ \mathrm{F}+(5)$ & $\mathrm{L}+/ \mathrm{F}+(10)$ & $\mathrm{L}+/ \mathrm{F}+\left(15^{*}\right)$ \\
\hline E. coli & $10^{6}$ & $10^{6}$ & $10^{6}$ & $8.16 \times 10^{3}$ & $4.08 \times 10^{3}$ & $1.59 \times 10^{3}$ \\
S. aureus & $10^{6}$ & $10^{6}$ & $10^{6}$ & 0 & 0 & 0 \\
C. perfrigens & $10^{6}$ & $10^{6}$ & $10^{6}$ & 0 & 0 & 0 \\
\hline
\end{tabular}

*minutes 
control group, without radiation and PS (L-F-). Similarly, when laser was applied singly (group $\mathrm{L}+$ (F-) the three different bacterial species grew similarly to control group. These data are consistent to the demonstration that methylene blue had no toxicity for bacterial cell. Also, it was evident that only light without the presence of PS was not able to promote microorganisms death.

The association of red laser and methylene blue showed complete inactivation of $S$. aureus and $C$. perfrigens when light was applied for $5 \mathrm{mi}-$ nutes in the presence of the PS, even when these bacteria were cultured along with E. coli after 24 hours of incubation. Several studies in literature corroborate this results, showing that 4 to $5 \mathrm{mi}-$ nutes of irradiation exposure time are sufficient to inactivate microorganisms $(20,21)$.

In relation to $E$. coli, there was no complete inactivation after 5 minutes of PDI, and even when exposure time was increased to 10 and 15 minutes. According to literature data, some factors may have influenced the non-complete elimination of bacteria, such as structural difference of the wall of Gram positive and Gram negative bacteria; the relative permeability of Gram positive membranes may be a facilitator of entrance of PS, and the more complex external membrane of Gram negative bacteria may work as a barrier to PS entrance. These data show that different bacteria, in special in relation to their different structures, make difficult a single therapy that can eliminate all kinds of bacteria $(22,23)$. This paper showed the efficiency of methylene blue as PS and of low potency red laser to inhibit the growth of all bacterial species studied. Therefore, it must be used as basis for in vivo studies.

\section{CONCLUSIONS}

The use of low potency red laser associated to PS methylene blue was efficient to inactivate prevalent bacteria in Fournier's Gangrene.

It was observed complete inactivation of S. aureus and Clostridium perfrigens bacteria in treated groups, regardless the time of exposure. In relation to E. coli, there was no complete inactivation, but it was observed a statistically significant reduction of these microorganisms.

\section{CONFLICT OF INTEREST}

\author{
None declared.
}

\section{REFERENCES}

1. Laucks SS 2nd. Fournier's gangrene. Surg Clin North Am. 1994;74:1339-52.

2. Wróblewska M, Kuzaka B, Borkowski T, Kuzaka P, Kawecki D, Radziszewski P. Fournier's gangrene--current concepts. Pol J Microbiol. 2014;63:267-73. Erratum in: Pol J Microbiol. 2015;64:60.

3. Fournier JA. Jean-Alfred Fournier 1832-1914. Gangrène foudroyante de la verge (overwhelming gangrene). Sem Med 1883. Dis Colon Rectum. 1988;31:984-8.

4. Paty R, Smith AD. Gangrene and Fournier's gangrene. Urol Clin North Am. 1992;19:149-62.

5. Crowell W, Roberts R, Tarry S. Fungal Fourniers Gangrene in na Immunocompromised Patient. Urol Case Rep. 2015;4:13.

6. Wainwright M. Photodynamic antimicrobial chemotherapy (PACT). J Antimicrob Chemother. 1998;42:13-28.

7. Gad F, Zahra T, Hasan T, Hamblin MR. Effects of growth phase and extracelular slime on photodynamic inactivation of gram-positive pathogenic bacteria. Antimicrob Agents Chemother. 2004;48:2173-8.

8. de Souza SC, Junqueira JC, Balducci I, Koga-Ito CY, Munin E, Jorge AO. Photosensitization of different Candida species by low power laser light. J Photochem Photobiol B. 2006;83:34-8.

9. Lambrechts SA, Aalders MC, Van Marle J. Mechanistic study of the photodynamic inactivation of Candida albicans by a cationic porphyrin. Antimicrob Agents Chemother. 2005;49:2026-34.

10. Demidova TN, Hamblin MR. Effect of cell-photosensitizer binding and cell density on microbial photoinactivation. Antimicrob Agents Chemother. 2005;49:2329-35.

11. Tardivo JP, Del Giglio A, de Oliveira CS, Gabrielli DS, Junqueira HC, Tada DB, et al. Methylene blue in photodynamic therapy: From basic mechanisms to clinical applications. Photodiagnosis Photodyn Ther. 2005;2:175-91.

12. Chatzopoulos GS, Doufexi AE. Photodynamic therapy in the treatment of aggressive periodontitis: A systematic review. Med Oral Patol Oral Cir Bucal. 2016;21:e192-200.

13. Kim MM, Penjweini R, Gemmell NR, Veilleux I, McCarthy A, Buller $\mathrm{G}$, et al. A feasibility study of singlet oxygen explicit dosmietry (SOED) of PDT by intercomparison with a singlet oxygen luminescence dosimetry (SOLD) system. Proc SPIE Int Soc Opt Eng. 2016;9694.

14. Brooks NA, O'Donnell MA. Treatment options in nonmuscle-invasive bladder cancer after BCG failure. Indian $\mathrm{J}$ Urol. 2015;31:312-9. 
15. Bozzini G, Colin P, Betrouni N, Nevoux P, Ouzzane A, Puech $P$, et al. Photodynamic therapy in urology: what can we do now and where are we heading? Photodiagnosis Photodyn Ther. 2012;9:261-73.

16. Junqueira JC, Ribeiro MA, Rossoni RD, Barbosa JO, Querido SM, Jorge A0. Antimicrobial photodynamic therapy: photodynamic antimicrobial effects of malachite green on Staphylococcus, enterobacteriaceae, and Candida. Photomed Laser Surg. 2010;28(Suppl 1):S67-72.

17. Maciel CM, Piva MR, Ribeiro MA, de Santana Santos T, Ribeiro CF, Martins-Filho PR. Methylene Blue-Mediated Photodynamic Inactivation Followed by Low-Laser Therapy versus Miconazole $\mathrm{Gel}$ in the Treatment of Denture Stomatitis. J Prosthodont. 2016;25:28-32.

18. Kharkwal GB, Sharma SK, Huang YY, Dai T, Hamblin MR. Photodynamic therapy for infections: clinical applications. Lasers Surg Med. 2011;43:755-67.

19. Fuchs BB, Tegos GP, Hamblin MR, Mylonakis E. Susceptibility of Cryptococcus neoformans to photodynamic inactivation is associated with cell wall integrity. Antimicrob Agents Chemother. 2007;51:2929-36.

20. Vilela SF, Junqueira JC, Barbosa JO, Majewski M, Munin E, Jorge AO. Photodynamic inactivation of Staphylococcus aureus and Escherichia coli biofilms by malachite green and phenothiazine dyes: an in vitro study. Arch Oral Biol. 2012;57:704-10.
21. Rolim JP, de-Melo MA, Guedes SF, Albuquerque-Filho FB, de Souza JR, Nogueira NA, et al. The antimicrobial activity of photodynamic therapy against Streptococcus mutans using different photosensitizers. J Photochem Photobiol B. 2012;106:40-6.

22. Harder KJ, Nikaido H, Matsuhashi M. Mutants of Escherichia coli that are resistant to certain beta-lactam compounds lack the ompF porin. Antimicrob Agents Chemother. 1981;20:549-52.

23. Jori G, Fabris C, Soncin M, Ferro S, Coppellotti O, Dei D, et al. Photodynamic therapy in the treatment of microbial infections: basic principles and perspective applications. Lasers Surg Med. 2006;38:468-81.

Correspondence address: Nalisson Marques Pereira Departamento de Engenharia Biomédica Universidade Brasil, São Paulo, SP Rua Carolina Fonseca, 235 São Paulo, SP, 08230-030, Brasil drnalisson@gmail.com 